\title{
PENGARUH MEDIA PEMBELAJARAN VIDEO SMART HAFIZ TERHADAP KETERAMPIAN BICARA ANAK
}

\author{
Dian Anggraeni ${ }^{1}$, Eva Gustiana ${ }^{2}$ \\ Prodi Pendidikan Anak Usia Dini, STKIP Muhammadiyah Kuningan ${ }^{2}$ \\ diananggraeny221095@gmail.com¹,eva_psikologi@upmk.ac.id ${ }^{2}$
}

\begin{abstract}
Abstrak
Tujuan penelitian untuk mengetahui pengaruh media pembelajaran video smart hafiz terhadap keterampilan bicara anak di KB Al-Hikmah. Penelitian ini merupakan penelitian quasi eksperimen. Populasi pada penelitian ini adalah anak usia dini kelompok A KB Al-Hikmah yang berjumlah 30 siswa sebagai kelompok eksperimen dengan penggunaan media smart hafiz. Teknik pengambilan sampel yang digunakan adalah total sampling sehingga sampel yang didapat adalah anak usia dini kelompok A KB Al-Hikmah yang berjumlah 30 siswa. Teknik pengumpulan data yang digunakan adalah tes keterampilan berbahasa. Teknik analisis data dalam penelitian ini adalah uji normalitas, uji homogenitas dan uji hipotesis (uji t) yang digunakan untuk mengetahui pengaruh media pembelajaran video smart hafiz terhadap keterampilan bicara anak di KB Al-Hikmah. Berdasarkan perhitungan statistik uji hipotesis dengan nilai $\mathrm{t}=54,077$ dengan Sig. 0,000 $<0,05 \mathrm{Hi}$ diterima artinya terdapat pengaruh media gambar terhadap pengaruh media pembelajaran video smart hafiz terhadap keterampilan bicara anak di KB Al-Hikmah. Kesimpulan dari penelitian ini adalah terdapat pengaruh media pembelajaran video smart hafiz terhadap keterampilan bicara anak di KB Al-Hikmah.
\end{abstract}

Kata Kunci : media pembelajaran, video smart hafiz, keterampilan bicara anak.

\begin{abstract}
The purpose of this study was to determine the effect of smart hafiz video learning media on children's speaking skills. This research is an quasi experimental research. The population in this study is the early childhood group A KB Al-Hikmah. which amounted to 30 students as an experimental group with the use of smart hafiz media. The sampling technique used was total sampling so that the samples obtained were the early childhood group A KB Al-Hikmah which numbered 30 students. The data collection technique used is a language skills test. The data analysis technique in this study is the normality test, homogeneity test and hypothesis test ( $t$ test) which is used to determine the effect of smart hafiz video learning media on children's speaking skills. Based on the statistical calculation of the hypothesis test with the value $t=54,077$ with Sig. 0,000<0,05 Hi accepted means that there is an influence of image media on the influence of smart hafiz video learning media on children's speaking skills. The conclusion of this study is that there is the influence of smart hafiz video learning media on children's speaking skills.
\end{abstract}

Keywords: learning media, smart video hafiz, children's speaking skills.

(C) 2019 Dian Anggraeni ${ }^{1}$, Eva Gustiana ${ }^{2}$ Under the license CC BY-SA 4.0

http://jurnal.upmk.ac.id/index.php/pelitapaud 


\section{PENDAHULUAN}

Dalam pembelajaran, seorang guru hendaknya mampu menciptakan suasana pembelajaran yang mampu mendorong siswa aktif belajar guna mendapatkan pengetahuan (knowledge), menyerap dan memantulkan nilai-nilai tertentu (value), dan terampil melakukan keterampilan tertentu (skill). Siswa akan mudah mengikuti pembelajaran jika pembelajaran berada dalam suasana yang menyenangkan.

Pendidikan Anak Usia Dini adalah usaha sadar dalam memfasilitasi pertumbuhan dan perkembangan jasmani dan rohani sejak lahir sampai usia enam tahun yang dilakukan melalui penyediaan pengalaman-pengalaman dan stimulus yang bertujuan untuk mengembangkan secara terpadu agar anak dapat berkembang secaraoptimal sesuai dengan norma dan harapan. Pada anak usia dini, keterampilan berbahasa yang paling umum dan efektif untuk dikembangkan adalah keterampilan membaca permulaan. Hal ini sesuai dengan karakteristik perkembangan anak pada usia tersebut, di antaranya anak mampu membaca dengan intonasi dan pelafalan yang baik. Akan tetapi kenyataan di lapangan, guru lebih menekankan pada keterampilan motorik halus dan kreativitas berbahasa lisan, sedangkan keterampilan berbicara siswa masih dikesampingkan dan dianggap kurang begitu penting.

Ayuanda (2015) mengemukakan dalam jurnal pendidikan anak usia dini "dalam aspek bahasa, guru memiliki peranan yang sangat penting untuk memberikan stimulasi dan menggembangkan aspek bahasa tersebut. Keterampilan barbahasa memiliki 4 komponen yaitu keterampilan menyimak (listening skills), Keterampilan berbicara (speaking skills), keterampilan membaca (reading skills), keterampilan menulis (writing skills). Dalam penelitian ini, penulis menitik-beratkan pada aspek bahasa yaitu keterampilan berbicara. Ada 4 komponen keterampilan berbicara yang harus diperhatikan yaitu: fonologi (bunyi), struktur kalimat, kosa kata, kelancaran (ketepatan).

Keterampilan berbicara adalah keterampilan berbahasa di mana siswa mampu berbicara dengan baik, berkomunikasi secara lisan, mampu melaksanakan perintah lisan, mendengarkan dan menceritakan kembali cerita sederhana, menyusun kalimat, dan mengenal tulisan atau simbol sederhana. Kemampuan berbicara dalam pembelajaran bahasa Indonesia sangat penting dimiliki oleh siswa yang meliputi pelafalan yang tepat, intonasi yang jelas dalam pengucapannya, pilihan kata yang 
tepat dalam berbicara serta penggunaan frase yang tepat.

Kamaluddin dan Aristya (2016) memaparkan hasil penelitiannya bahwa kegiatan berbicara di kelas kurang diasah oleh guru. Akibatnya, seringkali ditemukan kecendrungan anak tidak mau berbicara karena takut salah. Selain itu, anak kurang memahami kosakata yang baku dan malas mengungkapkan gagasan atau ide akibat kurang percaya diri. Kecendrungan ini akan berdampak pada tidak berkembangnya keterampilan berbicara yang dimiliki anak, sehingga tujuan pembelajaran akan sulit dicapai.

Berdasarkan survai pendahuluan, keterampilan berbicara anak KB AlHikmah masih rendah. Hal ini ditunjukkan dengan pelafalan yang kurang jelas, intonasi suara kurang tepat, dan berbicara dengan terbata-bata. Hal ini disebabkan pelaksanaan pembelajaran berpusat pada guru, kurangnya antusias anak dalam pembelajaran, penerapan metode dalam pembelajaran yang kurang sesuai, kurangnya variasi yang digunakan oleh guru saat mengajar, dan kurangnya media pembelajaran yang digunakan guru.

Berdasarkan permasalahan di atas, maka diperlukan adanya perubahan strategi mengajar guru. Guru sebagai pengelola pembelajaran hendaknya mampu memilih dan menentukan model, metode, maupun media yang akan digunakan dalam pembelajaran secara bijak. Penggunaan media pembelajaran yang tepat dapat meningkatkan motivasi belajar siswa. Menurut Kanifatul (2014: 37), "Siswa akan mudah mengikuti pembelajaran jika pembelajaran berada dalam suasana yang menyenangkan". Dengan adanya pembelajaran yang menyenangkan dan bebas dari tekanan, siswa akan lebih mudah memahami materi pelajaran yang disampaikan oleh guru. Salah satu media yang dapat digunakan dalam proses pembelajaran salah satunya adalah media video. Video merupakan salah satu jenis media pembelajaran yang berbasis audio-visual yang merangsang berfungsinya indera pendengaran dan indera penglihatan. Daryanto (2015: 88) menyatakan bahwa, "Media video dapat dimanfaatkan dalam program pembelajaran karena dapat memberikan pengalaman yang tidak terduga kepada siswa". Penelitian mengenai penggunaan video sebagai media pembelajaran pernah dilakukan oleh beberapa peneliti. Hasil penelitian yang dilakukan oleh Iwan Permana Suwarna (2014), menunjukkan bahwa pembelajaran yang menggunakan media video memiliki daya dukung terhadap hasil belajar pada kategori baik dengan persentase $79 \%$. 
Penelitian Thomas Adi Tri Nugroho (2015) menunjukkan bahwa hasil belajar kelas eksperimen lebih besar daripada hasil belajar kelas kontrol. Hasil belajar kelas eksperimen adalah 80,00; dan hasil belajar kelas kontrol adalah 70,86. Penelitian Tabah Listiyanto (2015), menunjukkan bahwa pembelajaran dengan pemanfaatan video edukasi sebagai media pembelajaran mempengaruhi motivasi belajar sebesar $44,1 \%$.

Perbedaan dengan penelitian terdahulu dengan penelitian yang akan dilaksanakan adalah penggunaan media videonya. Media video yang peneliti gunakan adalah media video Smart Hafiz merupakan Inovasi terbaru dari Al Qolam , produk edukasi anak-anak Islami yang memiliki banyak sekali konten edukasi dan juga Fun. Dengan kualitas suara yang sangat baik, smart hafiz ini memiliki fitur karaoke untuk media anak mengaji dan bernyayi.

Berdasarkan latar belakang tersebut, maka diperlukan adanya inovasi dalam rangka meningkatkan kualitas pembelajaran. Guru dapat menggunakan media pembelajaran seperti video smart hafiz sebagai salah satu cara untuk menarik perhatian siswa, sehingga pembelajaran berjalan santai namun materi tetap dapat disampaikan dengan baik. Menurut Daryanto (2015: 80), "Video dapat dimanfaatkan dalam program pembelajaran karena dapat memberikan pengalaman yang tidak terduga kepada siswa. Kemampuan video dalam memvisualisasikan materi terutama efektif untuk membantu menyampaikan materi yang bersifat dinamis". Dengan menayangkan video smart hafiz dalam pembelajaran, guru tidak hanya memanfaatkan fasilitas pembelajaran yang tersedia, namun melalui video edukasi pula siswa dapat belajar melalui peristiwa yang seolah-olah dialaminya sendiri, sehingga ingatan tentang materi yang disampaikan melalui video edukasi akan mudah diingat.

Penggunaan media video smart hafiz dapat melihat dan mengevaluasi apa yang telah didengar dan dilihat, dapat meningkatkan efektivitas pembelajaran, meningkatkan interaksi edukatif antara guru dengan siswa yang baik, meningkatkan aktivitas dan kreativitas siswa dalam proses pembelajaran serta meningkatkan hasil belajar siswa. (http/www.Smart Hafiz.com/2019/Media Pembelajaran Al-Qu'ran).

Media video smart hafiz memberikan dasar-dasar konkrit untuk berpikir, membuat pelajaran lebih menarik, memungkinkan hasil belajar lebih tahan lama, memberikan 
pengalaman-pengalaman yang nyata, mengembangkan keteraturan dan kontinuitas berpikir, dan memberikan pengalaman-pengalaman belajar serta meningkatkan hasil belajar siswa.

Penggunaan media video smart hafiz dalam pembelajaran dapat memberikan pengalaman-pengalaman yang nyata, mengembangkan keteraturan dan kontinuitas berpikir, dapat memberikan pengalaman-pengalaman belajar, memberikan dasar-dasar konkrit untuk berpikir, membuat pelajaran lebih menarik, dan memungkinkan hasil belajar lebih tahan lama. (http/www.Smart Hafiz.com/2019/Media Pembelajaran AlQu'ran).

\section{METODE PENELITIAN}

\section{Jenis Penelitian}

Metode merupakan cara utama yang dipergunakan untuk mencapai suatu tujuan, misalkan untuk menguji serangkaian hipotesis, dengan mempergunakan teknik serta alat- alat tertentu. Cara utama itu dipergunakan setelah penyelidikan memperhitungkan kewajarannya ditinjau dari tujuan penyelidikan serta dari situasi penyelidikan. Karena, pengertian metode penyelidikan adalah pengertian yang luas, yang biasanya perlu dijelaskan lebih eksplisit didalam setiap penyelidikan.
Metode yang digunakan dalam penelitian ini adalah metode quasy eksperimen. Dalam hal ini sebagaimana menurut Arikunto (2015:57) dijelaskan sebagai berikut:

"Quasy eksperimen adalah suatu cara untuk mencari hubungan sebab akibat (hubungan kasual) antara dua faktor yang sengaja ditimbulkan oleh penelitian dengan menggelimir atau mengurangi atau menyisihkan faktorfaktor yang mengganggu. Eksperimen selalu dilakukan dengan maksud untuk meneliti akibat dari suatu perlakuan.”

\section{Waktu dan tempat penelitian}

Pelaksanaan dilakukan pada bulan Maret 2019 bertempat di KB AL Hikmah Desa Cengal Kecamatan Japara.

\section{HASIL PENELITIAN DAN PEMBAHASAN}

Pelaksanaan pembelajaran dengan menggunakan media video smart hafiz dimulai dengan kegiatan pembukaan \pm 30 menit meliputi : salam, berdoa, membaca syair sayuran, absensi, dan berjalan pada garis lurus. Kegiatan inti meliputi kegiatan mengamati dengan mempersiapkan alat peraga untuk kegiatan yang akan dilaksanakan, anak mengamati langsung media yang sudah disiapkan. Kegiatan menanya, meliputi anak didorong untuk bertanya tentang 
objek yang di amati, guru mengarahkan anak agar menarik minat anak bertanya tentang alat bahan yang disediakan, mengumpulkan Informasi, menalar dan mengkomunikasikan, guru merespon pertanyaan anak dan menyiapkan berbagai kegiatan yang bisa menjawab pertanyaan anak, anak mengapresiasikan hasil karya.

Guru memberikan contoh penggunaan video smart hafiz berupa menyajikan film animasi anak tentang pendidikan dan ibadah. Anak-anak menyimak guru menggunakan video smart hafiz tentang film animasi anak tentang pendidikan dan ibadah. Guru memberikan kesempatan kepada anak untuk berbicara di depan kelas

Recalling dengan merapikan mainan, diskusi tentang perasaan selama kegiatan, menunjukan hasil karyanya, pengetahuan pengetahuan anak. Kegiatan penutup meliputi berdiskusi kegiatan yang sudah dimainkan hari ini, menanyakan perasaan kegiatan hari ini, informasi kegiatan esok hari.

Dalam pembelajaran, peneliti juga melakukan pengamatan atau observasi aktivitas anak dalam pembelajaran keterampilan bicara anak dengan penggunaan media pembelajaran video smart hafiz. Melalui observasi dihasilkan data observasi berupa aktivitas belajar anak selama pembelajaran berlangsung.

Keterampilan Bicara Anak di KB AlHikmah

Sebelum melaksanakan pembelajaran peneliti melaksanakan tes awal pembelajaran dengan tes keterampilan bicara anak dengan kriteria penilaian yaitu : pelafalan, intonasi, penghayatan dan ekspresi. Tes dilaksanakan pada kelas eksperimen yang menggunakan media pembelajaran video smart hafiz.

Data pretest diperoleh dari hasil tes keterampilan bicara anak pada kelas eksperimen yang menggunakan media pembelajaran video smart hafiz pada $\mathrm{KB}$ Al-Hikmah. Data pretest yang dilaksanakan pada awal pembelajaran digunakan untuk mengetahui keterampilan bicara anak di KB AlHikmah sebelum penerapan media pembelajaran video smart hafiz. 


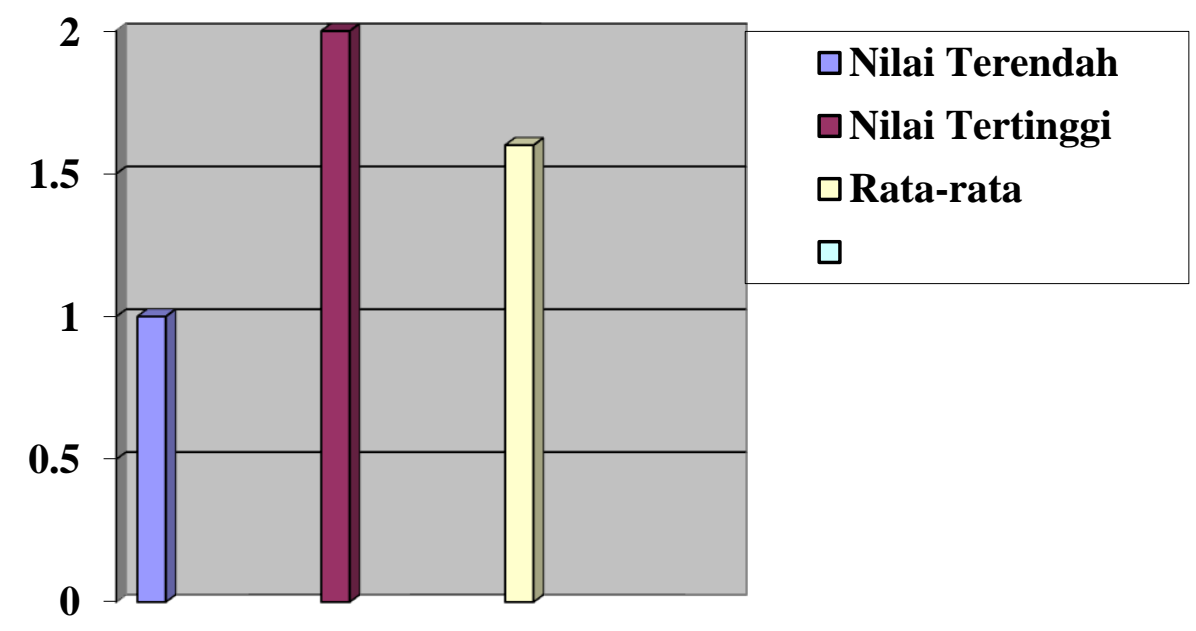

Gambar 1. hasil pretest keterampilan bicara anak kelas eksperimen.

Pada gambar 1 membuktikan bahwa data hasil pretest keterampilan bicara anak di KB Al-Hikmah sebelum penerapan media pembelajaran video smart hafiz memperoleh skor terendah bintang 1 dengan jumlah 12 anak kriteria belum berkembang, skor tertinggi bintang 2 dengan jumlah 18 anak kriteria mulai berkembang dan memperoleh rata-rata sebesar 2 dengan jumlah 18 anak kriteria mulai berkembang, hal ini membuktikan bahwa keterampilan bicara anak di KB AlHikmah sebelum penerapan media pembelajaran video smart hafiz masih rendah.

Setelah melaksanakan pembelajaran peneliti melaksanakan tes akhir pembelajaran dengan tes keterampilan bicara anak dengan kriteria penilaian yaitu pelafalan, intonasi, penghayatan dan ekspresi. data hasil posttest keterampilan bicara anak di KB Al-Hikmah setelah penerapan media pembelajaran video smart hafiz memperoleh skor terendah bintang 2 dengan mulai berkembang, skor tertinggi bintang 4 dengan kriteria berkembang sangat baik dan memperoleh rata-rata sebesar 3 dengan kriteria berkembang sesuai harapan, hal ini membuktikan bahwa penerapan media pembelajaran video smart hafiz sangat berhasil meningkatkan keterampilan bicara anak di KB Al-Hikmah.

Adapun hasil posttest keterampilan bicara anak pada kelas eksperimen yang menggunakan penerapan media pembelajaran video smart hafiz pada $\mathrm{KB}$ Al-Hikmah. 


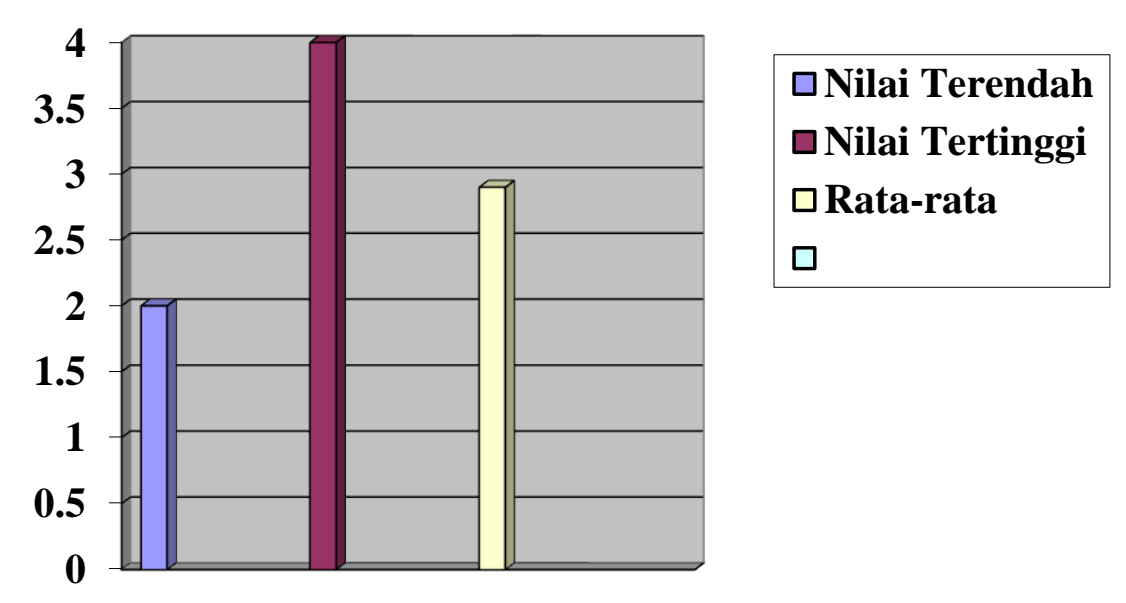

Gambar 2. Hasil posttest hasil tes keterampilan bicara anak kelas eksperimen

Pada gambar 2 membuktikan bahwa data hasil posttest keterampilan bicara anak di KB Al-Hikmah setelah penerapan media pembelajaran video smart hafiz memperoleh skor terendah bintang 2 dengan jumlah 3 anak mulai berkembang, skor tertinggi bintang 4 dengan jumlah 1 anak kriteria berkembang sangat baik dan memperoleh rata-rata sebesar 3 dengan jumlah 26 anak kriteria berkembang sesuai harapan, hal ini membuktikan bahwa penerapan media pembelajaran video smart hafiz sangat berhasil meningkatkan keterampilan bicara anak di KB Al-Hikmah.

Hasil pretest dan posttest keterampilan bicara anak kelas eksperimen dapat dijadikan alat ukur untuk peningkatan keterampilan bicara anak di PAUD At-Taqwa. Adapun Adapun hasil pretest dan posttest keterampilan bicara anak pada kelas eksperimen yang menggunakan penerapan media pembelajaran video smart hafiz pada PAUD At-Taqwa. 


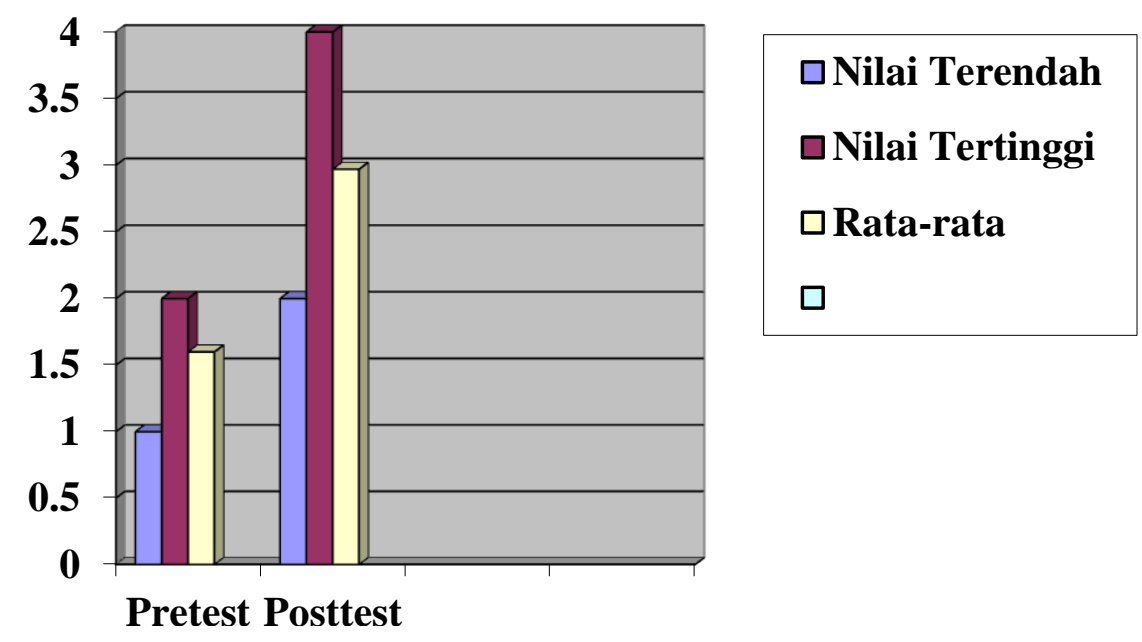

Gambar 3. Hasil pretest dan posttest keterampilan bicara anak kelas eksperimen

Pada gambar 3 membuktikan bahwa data hasil pretest keterampilan bicara anak di KB Al-Hikmah sebelum penerapan media pembelajaran video smart hafiz memperoleh skor terendah bintang 1 dengan jumlah 12 anak kriteria belum berkembang, skor terendah bintang 2 dengan jumlah 18 anak kriteria mulai berkembang dan memperoleh rata-rata sebesar 2 dengan jumlah 18 anak kriteria mulai berkembang. Sedangkan data hasil posttest keterampilan bicara anak di $\mathrm{KB}$ Al-Hikmah setelah penerapan media pembelajaran video smart hafiz memperoleh skor terendah bintang 2 dengan jumlah 3 anak mulai berkembang, skor tertinggi bintang 4 dengan jumlah 1 anak kriteria berkembang sangat baik dan memperoleh rata-rata sebesar 3 dengan jumlah 26 anak kriteria berkembang sesuai harapan, hal ini membuktikan bahwa penerapan media pembelajaran video smart hafiz sangat berhasil meningkatkan keterampilan bicara anak di KB AlHikmah.

\section{SIMPULAN}

Berdasarkan hasil pengolahan data dan pembahasan tentang pengaruh media pembelajaran video smart hafiz terhadap keterampilan bicara anak di KB AlHikmah, maka penulis menarik kesimpulan bahwa Penerapan media pembelajaran video smart hafiz di KB AlHikmah termasuk kategori baik serta aktivitas anak termasuk kriteria berkembang sesuai harapan. Keterampilan bicara anak di KB Al-Hikmah setelah penerapan media pembelajaran video smart hafiz memperoleh rata-rata sebesar 3 dengan kriteria berkembang sesuai harapan. Terdapat pengaruh media pembelajaran video smart hafiz terhadap keterampilan bicara anak di KB Al- 
Hikmah hal ini ditunjukkan dari hasil perhitungan uji hipotesis diperoleh uji hipotesis dengan nilai $\mathrm{t}=54,077$ dengan Sig. 0,000<0,05 maka Hi diterima.

\section{DAFTAR PUSTAKA}

Ali. (2015). Media pembelajaran. Jakarta: Bumi Aksara.

Arikunto, Suharsimi. (2015). Prosedur penelitian, Suatu Pendekatan Praktek. Jakarta: Rineka Cipta.

Arsyad, A. (2014). Media pembelajaran. Jakarta: PT. Raja Grafindo Persada.

Ayuanda. (2015). "Pengaruh Media Video terhadap Kemampuan Berbicara Anak". (Online). Jurnal. Pendidikan Guru Pendidikan Anak Usia Dini FKIP UNS Tersedia :http://psbpsma.org/content/blog/3992media_video (diakses 21 Februari 2019). Hal : 33-34

Rohani. (2015). Peranan Media dalam Pembelajaran. Jakarta. Bumi Aksara

Daryanto. (2015). Peranan Media dalam Pembelajaran. Jakarta. Bumi Aksara

Devi Pujiawati. (2015). Pengaruh Media Video Animasi untuk Meningkatkan Kemampuan Berbicara Anak PAUD Al Barkah Indramayu. Jurnal Pendidikan PGPAUD

Erwin Permana. (2017). Pemanfaatan media pembelajaran boneka kaus kaki dapat meningkatkan keterampilan berbicara siswa . Jurnal Pendidikan PGPAUD.

Farris. (2013). Panduan Belajar Bahasa dan Sastra Indonesia. Bandung: Erlangga.

Febri Ferbrianti. (2016). Pengaruh Metode Bermain Peran terhadap Kemampuan Berbicara Anak PAUD Al-Imam Banjarmasin. Jurnal Pendidikan PGPAUD .
Hadi, Sutrisno. (2015). Statistik untuk Penelitian. Jakarta : Pustaka Setia

Hamalik, Oemar. (2015). Proses belajar mengajar. Jakarta: Bumi Aksara.

Iwan Permana Suwarna. (2014). "Penggunaan Media Visual Kartun untuk Meningkatkan Kemampuan Berbicara Anak". (Online). Jurnal. Pendidikan Guru Pendidikan Anak Usia Dini FKIP. Tersedia psma.org/content/blog/3992media_video (diakses 21 Februari 2019).

Kamiluddin dan Aristya. (2016). "Pengaruh Media Video Kartun terhadap Kemampuan Berbicara Anak”. (Online). Jurnal. Pendidikan Guru Pendidikan Anak Usia Dini FKIP UPI Tersedia :http://psbpsma.org/content/blog/3992media_video (diakses 21 Februari 2019).

Kusumah. (2013). Media pembelajaran. Bandung: Pustaka Setia.

Kuswanto. (2014). Keterampilan Berbicara dalam Pembelajaran Bahasa Indonesia. Bandung: Erlangga.

Latuheru. (2016). Media pembelajaran. Surabaya : Kartika

Munadi, Yudhi. (2014). Media pembelajaran, sebuah pendekatan baru. Jakarta: Gaung Persada Press.

Nasir, Muhammad. (2015). Metodologi Penelitian. Bandung : Permadi.

Nera Ayuandia. (2015). Penerapan metode karyawisata dapat meningkatkan keterampilan berbicara pada anak kelompok B Taman Kanak-Kanak Lab School PAUD UNIB Kota Bengkulu. Jurnal Pendidikan PGPAUD.

Nurwanti, Vera. (2010). Penerapan metode abjad dapat meningkatkan kemampuan berbicara anak di TK Nurul Hidayah Bogor. Jurnal Pendidikan PGPAUD. 
Purnamasari. (2014). Belajar dan Pembelajaran. Bandung : PT Remaja Rosdakarya

Raharjo. (2015). Media pembelajaran. Jakarta: Bumi Aksara

Rohani. (2015). Peranan Media dalam Pembelajaran. Jakarta. Bumi Aksara

Sardiman, A.M. (2016). Interaksi dan motivasi belajar mengajar. Jakarta: PT Raja Grafindo Persada.

Sri Handayani. (2016). Penerapan Media Visual Kartun untuk Meningkatkan Kemampuan Berbicara Anak TK AlIstiqomah Majalengka. Jurnal Pendidikan PGPAUD.

Sugiyono. (2016). Statistik untuk Penelitian. Bandung : Alfhabeta.

Sudjana, Nana. (2015). Media pembelajaran. Jakarta: PT. Raja Grafindo Persada.

Surakhman, Winarno. (2008). Statistik untuk Penelitian. Surabaya : Kartika.

Tarigan. Djago.( 2008). Membina Keterampilan Menulis Paragraf dan Pengembangannya. Bandung : Angkasa.

Thomas Adi Tri Nugroho. (2015). "Penggunaan Media Visual Kartun untuk Meningkatkan Kemampuan Berbicara Anak". (Online). Jurnal. Tersedia :http://psbpsma.org/content/blog/3992-

media_video (diakses 21 Februari 2019).

Widodo. (2014). Keterampilan Berbahasa. Jakarta : Bumi Aksara.

Yusuf, Muhammad. (2015). Keterampilan Berbicara dalam Pembelajaran Bahasa Indonesia. Bandung : Pustaka Setia 